\title{
Mass Spectrometric Study on Phosphorus in Molten Carbon- saturated Iron
}

\author{
Takashi NAGAI, Masao MIYAKE, Yoshitaka MITSUDA, Hisao KIMURA and Masafumi MAEDA \\ Institute of Industrial Science, The University of Tokyo, 4-6-1 Komaba, Meguro-ku, Tokyo 153-8505 Japan.
}

(Received on September 21, 2006; accepted on November 17, 2006)

The vapor pressure of phosphorus in molten carbon-saturated iron with phosphorus content of 0.20 0.92 mass $\%$ at $1473-1673 \mathrm{~K}$ was measured by double Knudsen cell mass spectrometry. In the molten carbon-saturated iron, phosphorus behaved according to Henry's law in the composition range. The activity coefficient of phosphorus in this conditions relative to infinite dilute solution, $f_{p}$, and the interaction parameter of carbon on phosphorus in molten iron, $e_{p}^{\prime C}$, were determined to be as follows:

$$
\log f_{P}=-\frac{300}{T}+0.82( \pm 0.05), \quad e_{P}^{\prime C}=\frac{120}{T}+0.061( \pm 0.010)
$$

KEY WORDS: activity of phosphorus; activity coefficient; interaction parameter; double Knudsen cell mass spectrometry.

\section{Introduction}

Hot metal pretreatment for de-phosphorization is a common practice in the iron and steel industry, and has been developed as an effective refining process. Thermodynamic properties of phosphorus in molten $\mathrm{Fe}-\mathrm{P}-\mathrm{C}$ alloy are important in improving this process.

Many researchers have reported these thermodynamic data. $^{1-12)}$ Although most of the reports ${ }^{1-7)}$ are on the interaction parameter of carbon on phosphorus in molten iron in the range of low carbon content, data at a high or saturated carbon content are required to discuss de-phosphorization in the process. Ban-ya and Suzuki, ${ }^{8)}$ and Hardry et al., ${ }^{9,10)}$ respectively, reported the thermodynamic properties of phosphorus in carbon-saturated iron ( $\mathrm{Fe}-\mathrm{P}-\mathrm{C}$ (sat.) alloy) at 1773 and $1873 \mathrm{~K}$ which they obtained by measuring the distribution of phosphorus between $\mathrm{Fe}-\mathrm{C}$ (sat.) alloy and silver. The data at $1788 \mathrm{~K}$ was obtained by Schenck and Hinze $^{11)}$ with the partial pressure measurements of $\mathrm{P}_{2}$ in equilibrium with $\mathrm{Fe}-\mathrm{P}-\mathrm{C}$ (sat.) alloy. Their experimental temperatures were, however, much higher than the de-phosphorization temperature in the actual hot metal pretreatment process, $1573 \mathrm{~K}$, and the phosphorus content they studied, 5-20 mass $\%$, was also much higher. Tsukihashi et $a l .{ }^{12)}$ obtained the activity coefficient of phosphorus in molten carbon-saturated iron and the interaction parameter of carbon on phosphorus in molten iron for low phosphorus contents at $1473-1673 \mathrm{~K}$ by an indirect method. They measured the distribution of phosphorus between $\mathrm{Fe}$ $\mathrm{C}$ (sat.) and $\mathrm{CaO}-\mathrm{CaF}_{2}-\mathrm{SiO}_{2}$ flux saturated with $\mathrm{CaO}$ and $3 \mathrm{CaO} \cdot \mathrm{SiO}_{2}$, and that between silver and the same flux under the atmosphere where the partial pressure of carbon monoxide was controlled.
In this study, the thermodynamic properties of phosphorus in molten carbon-saturated iron were investigated by measuring the vapor pressure of phosphorus in $\mathrm{Fe}-\mathrm{P}-$ C(sat.) alloy at 1473-1673 K with double Knudsen cell mass spectrometry.

\section{Experimental}

Knudsen cell mass spectrometry was developed as a method to measure vapor pressures of alloys and compounds. In this method, vapor pressure is measured as ion current which is proportional to the pressure. The pressure, $p_{i}$, and ion current of $i$-species, $I_{i}$, measured by mass spectrometer are related through the following fundamental equation: ${ }^{13)}$

$$
p_{i}=\frac{T}{S_{i}} I_{i}
$$

where $T$ is the absolute temperature of a sample and $S_{i}$ is the device dependent constant which includes such factors as ionization cross-section and efficiency of the ion detector. The usual accuracy of the data determined by single Knudsen cell mass spectrometry is not always sufficient, since the constancy of the device dependent constant $S_{i}$ is difficult to maintain over a long period and the reproducibility of each experimental run may not be good. To overcome this problem, a technique using double Knudsen cells has been developed. ${ }^{13-15)}$ The double Knudsen cells allow the measurement of ion currents of evaporated species from two substances under identical conditions in a single experiment: one substance is a sample alloy and the other taken as a reference substance, which is typically pure substance $i$. In this case, the device dependent constant can 
be regarded as equivalent for both substance, and thus activity can be deduced directly:

$$
a_{i}=\frac{p_{i}}{p_{i}^{0}}=\frac{I_{i}}{I_{i}^{0}}
$$

where $p_{i}^{0}$ and $I_{i}^{0}$ are the vapor pressure and the ion current of species $i$ in equilibrium with the reference substance, respectively. However, when measuring vapor pressures of phosphorus, a pure condensed substance cannot be used as a reference specimen at over $600 \mathrm{~K}$ since its stable phase is a gas at such temperatures. In this study, $\mathrm{Cu}-\mathrm{P}$ alloy was used as the reference substance instead of pure phosphorus. A previous study confirmed that the pressure of phosphorus in $\mathrm{Cu}-\mathrm{P}$ alloys could be properly measured by Knudsen cell mass spectrometry, and phosphorus in liquid copper behaves according to Henry's law in a content range of less than 2.21 mass $\%{ }^{15)}$ The phosphorus concentration of $\mathrm{Cu}-\mathrm{P}$ alloy used as the reference substance in the present study was 0.51 mass $\%$. The partial pressure of $\mathrm{P}_{2}$ in equilibrium with this alloy at the experimental temperature, $p_{\mathrm{P}_{2} \text { in } \mathrm{Cu}-\mathrm{P} \text {, }}$ can be calculated with the following data ${ }^{16)}$ :

$$
\begin{aligned}
\frac{1}{2} \mathrm{P}_{2}(\mathrm{~g}) & =\underline{\mathrm{P}}(1 \mathrm{mass} \% \text { in liquid copper }) \\
\Delta G_{3}^{\circ} & =-125000+0.54 T(\mathrm{~J})
\end{aligned}
$$

The partial pressure of $\mathrm{P}_{2}$ in equilibrium with $\mathrm{Fe}-\mathrm{P}-$ $\mathrm{C}$ (sat.) alloys, $p_{\mathrm{P}_{2} \text { in Fe-P-C(sat.) }}$, is represented by

$$
p_{\mathrm{P}_{2} \text { in Fe-P-C(sat.) }}=\frac{I_{\mathrm{P}_{2} \text { in Fe-P-C(sat.) }}}{I_{\mathrm{P}_{2} \text { in } \mathrm{Cu}-\mathrm{P}}} p_{\mathrm{P}_{2} \text { in } \mathrm{Cu}-\mathrm{P}}
$$

where $I_{\mathrm{P}_{2} \text { in Cu-P }}$ and $I_{\mathrm{P}_{2} \text { in Fe-P-C(sat.) }}$ are the ion currents of $\mathrm{P}_{2}$ from $\mathrm{Cu}-\mathrm{P}$ and $\mathrm{Fe}-\mathrm{P}-\mathrm{C}$ (sat.) alloys, respectively.

Figure 1 shows a schematic of the equipment for double Knudsen cell mass spectrometry used in this study. Evaporated species from the substance in two cells were successively detected by a mass spectrometer by rotating the cell holder. The Knudsen cell assembly consists of a Mo outer cell and a graphite inner cell. The dimensions of the Mo outer cell are $10 \mathrm{~mm}$ o.d., $8 \mathrm{~mm}$ i.d., and $18 \mathrm{~mm}$ height. Diameters of the graphite inner cell are $6 \mathrm{~mm}$ o.d., $4 \mathrm{~mm}$ i.d., and the height is $12 \mathrm{~mm}$. The lid of the outer cell has an orifice with a diameter of $0.4 \mathrm{~mm}$.

According to Knudsen, ${ }^{17)}$ the diameter of the orifice of a Knudsen cell must be less than one tenth of the mean free path of evaporated species so that Knudsen effusion is achieved. Mita et al., ${ }^{18)}$ by measuring the vapor pressure of

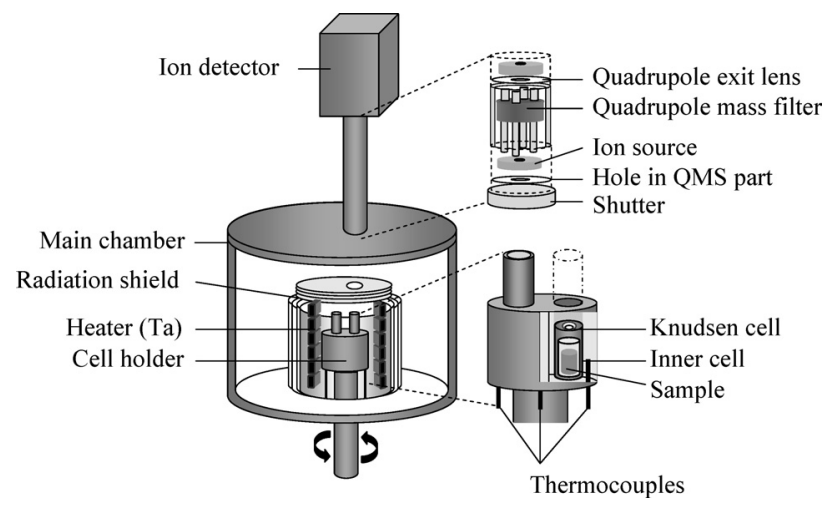

Fig. 1. Schematic configuration of double Knudsen cell mass spectrometry equipment. zinc, demonstrated that the ion current proportional to partial pressure was detected. The orifice of Knudsen cell in this study provides an equilibrium condition between gaseous and condensed phases at the experimental temperature. About $0.5 \mathrm{~g}$ of a sample or reference substance was charged in the Knudsen cell. The samples were set in the cell with $c a$. $0.1 \mathrm{~g}$ carbon powder to assure carbon-saturated condition. The cells were heated by a Ta electric resistance heating element in a vacuum chamber. The temperature was controlled within $\pm 1 \mathrm{~K}$ by using a Pt/13\%Rh-Pt thermocouple placed in the nearby heating element and a PID-type thermoregulator. The temperatures of cells and samples were measured by the three $\mathrm{Pt} / 13 \% \mathrm{Rh}-\mathrm{Pt}$ thermocouples that were put in holes drilled at the bottom of the cell holder.

A quadrupole mass spectrometer (QMS, H200M, Leybold Inficon) was used to monitor and measure ion currents of evaporated species. The QMS was placed on the top of the vacuum chamber in which the Knudsen cell unit was installed. The inside of the chamber was evacuated by a rotary pump and a turbo molecular pump, and the total residual gas pressure was kept below $3 \times 10^{-4} \mathrm{~Pa}$ during the experiments. The atomic or molecular beams of evaporated species from the Knudsen cell were injected into the ion source in QMS, where they were converted into positive ions by the impact of electrons emitted from the heated filament. Emission current of the filament and ionization potential were set to $2000 \mu \mathrm{A}$ and $1.634 \times 10^{-17} \mathrm{~J}(102 \mathrm{eV})$, respectively; these are based on the maximum production of Ar ions. ${ }^{19)}$ Although the appearance potential for Ar ions is higher than that of phosphorus, that value is applied to produce the ions of phosphorus. ${ }^{19)}$ The ions in the ion source were injected into the quadrupole mass filter, which rejected all except those of a specific mass-to-charge ratio $(\mathrm{m} / \mathrm{z})$; thereafter masses were detected by an electron multiplier.

Carbon-saturated iron containing phosphorus, $\mathrm{Fe}-\mathrm{P}-$ $\mathrm{C}$ (sat.) alloys, were prepared by melting electrolytic iron (Fe, 99.99\%), iron phosphide $\left(\mathrm{Fe}_{3} \mathrm{P}, 99.9 \%\right)$, and carbon powder $(\mathrm{C}, 99.9 \%)$ at $1473 \mathrm{~K}$ under an inert argon (Ar, 99.99\%) atmosphere using a SiC resistance furnace with mullite reaction tube of $60 \mathrm{~mm}$ o.d., $52 \mathrm{~mm}$ i.d., and $1000 \mathrm{~mm}$ length. About $100 \mathrm{~g}$ of master alloy was melted in a graphite crucible of $30 \mathrm{~mm}$ o.d., $20 \mathrm{~mm}$ i.d., and 100 $\mathrm{mm}$ height and about $10 \mathrm{~g}$ of the alloy was sucked out from the melt by a silica tube $3.0 \mathrm{~mm}$ in o.d. and $2.4 \mathrm{~mm}$ in i.d., followed by quenching in water. Phosphorus concentrations of the alloys were determined by inductively coupled plasma atomic spectroscopy (ICP-AES). Carbon concentrations were determined by fusion-infrared absorptiometry.

Copper-phosphorus alloys were prepared by melting pure copper $(\mathrm{Cu}, 99.9 \%)$ and copper phosphide $\left(\mathrm{Cu}_{3} \mathrm{P}, 99.9 \%\right)$ under the same condition as the $\mathrm{Fe}-\mathrm{P}-\mathrm{C}($ sat.) alloys preparation. The $\mathrm{P}$ concentration was confirmed to be 0.51 mass \% by ICP-AES.

\section{Results and Discussion}

The chemical compositions of the $\mathrm{Fe}-\mathrm{P}-\mathrm{C}($ sat.) alloys are given in Table 1. As the phosphorus content in the car- 
Table 1. Chemical composition of $\mathrm{Fe}-\mathrm{P}-\mathrm{C}($ sat.) alloys prepared.

\begin{tabular}{ccc}
\hline$\#$ & P content, [\%P] / mass\% & C content, [\%C] / mass\% \\
\hline 1 & 0.20 & 4.40 \\
2 & 0.35 & 4.39 \\
3 & 0.54 & 4.35 \\
4 & 0.72 & 4.29 \\
5 & 0.92 & 4.24 \\
\hline
\end{tabular}

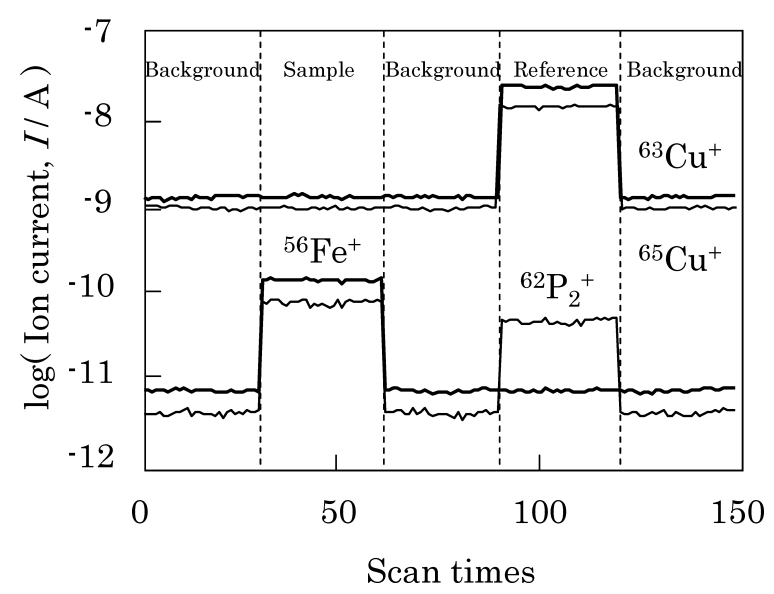

Fig. 2. The iron currents during the measurement at $1673 \mathrm{~K}$.

bon-saturated iron increased, the saturated concentration of carbon decreased. This implies that the interaction parameter of phosphorus on carbon in iron, $e_{\mathrm{C}}^{\mathrm{P}}$, is positive. Therefore, the interaction parameter of carbon on phosphorus in iron, $e_{\mathrm{P}}^{\mathrm{C}}$, is also positive.

The vapor pressure of phosphorus in the $\mathrm{Fe}-\mathrm{P}-\mathrm{C}$ (sat.) alloys was measured at $1473-1673 \mathrm{~K}$ by double Knudsen cell mass spectrometry using $0.51 \mathrm{mass} \% \mathrm{P}-\mathrm{Cu}$ alloy as a reference substance. The mass spectrometer detected stable ion currents at $m / z=56$ and 62 from $\mathrm{Fe}-\mathrm{P}-\mathrm{C}$ (sat.) alloy and those of 62,63 , and 65 from $\mathrm{Cu}-\mathrm{P}$ alloy. The $m / z=56,62$, 63 , and 65 correspond to ${ }^{56} \mathrm{Fe}^{+},{ }^{31} \mathrm{P}_{2}{ }^{+},{ }^{63} \mathrm{Cu}^{+}$, and ${ }^{65} \mathrm{Cu}^{+}$, respectively. These ion currents during a measurement at $1673 \mathrm{~K}$ are shown in Fig. 2. The ion currents of sample and reference substance were each scanned 30 times between the measurements of background. The differences between the average ion currents of sample or reference substance and that of background were taken as the net ion currents of samples or reference substance.

The ratio of ion currents of ${ }^{63} \mathrm{Cu}^{+}$and ${ }^{65} \mathrm{Cu}^{+}, I_{63} / I_{65}$, was $2.23 \pm 0.2$. This value is in good agreement with the natural isotope abundance of copper, ${ }^{63} \mathrm{Cu} /{ }^{65} \mathrm{Cu}=2.24 .{ }^{20}$ ) The ion currents of the iron isotopes ${ }^{54} \mathrm{Fe},{ }^{57} \mathrm{Fe}$, and ${ }^{58} \mathrm{Fe}$ were not detected since their abundance ratios are too small to detect by this equipment. It is well known that $\mathrm{P}, \mathrm{P}_{2}$, and $\mathrm{P}_{4}$ exist as gaseous phosphorus species and that $\mathrm{P}_{2}$ is the dominant species of phosphorus in this temperature range. However, only the ion current of $\mathrm{P}_{2}$ could be measured; those at $m / z=31$ and 124 , which correspond to ${ }^{31} \mathrm{P}^{+}$and ${ }^{31} \mathrm{P}_{4}{ }^{+}$, were not detected. The partial pressures of $\mathrm{P}, \mathrm{P}_{2}$, and $\mathrm{P}_{4}$ in equilibrium with the $\mathrm{Cu}-\mathrm{P}$ alloy at $1573 \mathrm{~K}$ are calculated to be $2.7 \times 10^{-4}, 1.5 \times 10^{-3}$, and $4.3 \times 10^{-12} \mathrm{~Pa}$, respectively, using reference data. ${ }^{16)}$ The pressure of $\mathrm{P}_{4}$ was too low to be detected. Although the pressure of $\mathrm{P}$ seemed high enough to be measured, its ion current could not be detected because

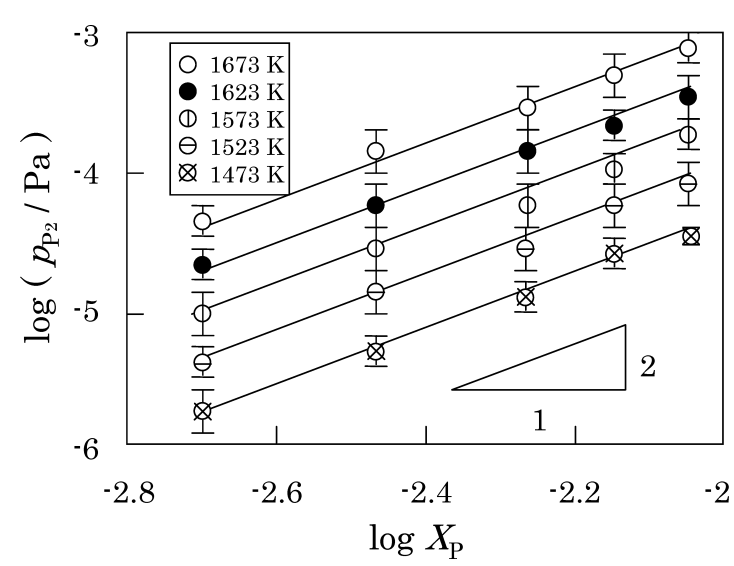

Fig. 3. Relationship between vapor pressure of $\mathrm{P}_{2}$ and phosphorus content in $\mathrm{Fe}-\mathrm{P}-\mathrm{C}$ (sat.) alloys.

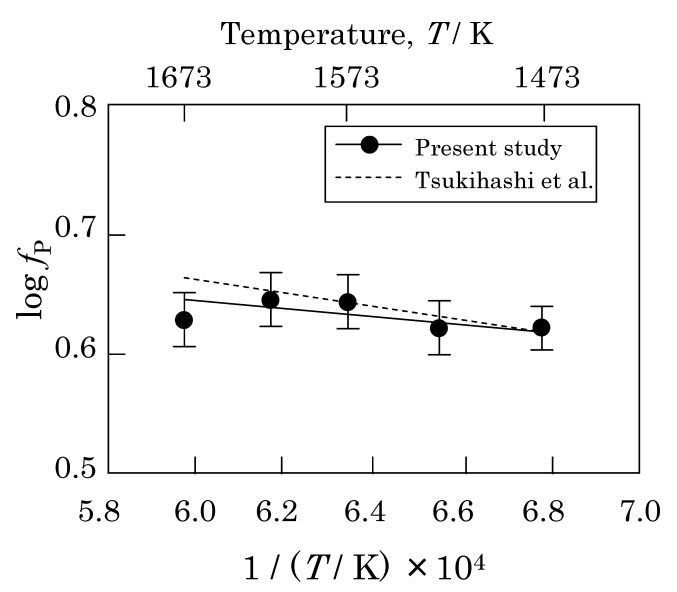

Fig. 4. Activity coefficient of phosphorus in molten carbon-saturated iron as a function of temperature.

of high background current at $m / z=31$.

The pressure of $\mathrm{P}_{2}$ in equilibrium with $\mathrm{Fe}-\mathrm{P}-\mathrm{C}$ (sat.) alloys was calculated by using Eq. (4). The relationship between the pressure of $\mathrm{P}_{2}$ and mole fraction of phosphorus, $X_{\mathrm{P}}$, in alloy is shown in Fig. 3. The logarithmic plot of the $\mathrm{P}_{2}$ pressure against the phosphorus content in the $\mathrm{Fe}-\mathrm{P}-$ $\mathrm{C}$ (sat.) alloy showed linearity and its slope was very close to 2 . This result indicates that the $\mathrm{Fe}-\mathrm{P}-\mathrm{C}$ (sat.) alloy was in equilibrium with $\mathrm{P}_{2}$ under the experimental conditions and that phosphorus in carbon-saturated iron behaved according to Henry's law in the composition range.

The activity coefficient of phosphorus in molten iron saturated with carbon, $f_{\mathrm{P}}$, was determined using the free energy change for the dissolution of phosphorus gas to pure liquid iron (Eq. (5)). ${ }^{21)} f_{\mathrm{P}}$ denotes the activity coefficient of phosphorus in molten iron with reference to infinite dilution.

$$
\begin{aligned}
\frac{1}{2} \mathrm{P}_{2}(\mathrm{~g}) & =\underline{\mathrm{P}}(1 \mathrm{mass} \% \text { in liquid iron }) \\
\Delta G_{5}^{\circ} & =-157700+5.4 T(\mathrm{~J})
\end{aligned}
$$

Figure 4 shows the logarithmic values for $f_{\mathrm{P}}$ as the function of temperature. An analytical equation is given as

$$
\log f_{\mathrm{P}}=\frac{300}{T}+0.82( \pm 0.05)
$$

The $f_{\mathrm{P}}$ obtained in the present study is in good agreement 
with that reported by Tsukihashi et al., ${ }^{12)}$ which is described by the dotted line in Fig. 4.

Although interaction parameters should be used essentially for dilute solution, the interaction parameter of carbon on phosphorus for the carbon-saturated iron, $e_{\mathrm{P}}^{\prime \mathrm{C}}$, was calculated in the same manner as dilute solution. The interaction parameter determined in the carbon-saturated system is indicated by $e^{\prime}$ to distinguish it from the usual ones.

Because phosphorus in $\mathrm{Fe}-\mathrm{P}-\mathrm{C}$ (sat.) alloys obeys Henry's law in the experimental range of phosphorus content, the self-interaction parameter of phosphorus, $e_{\mathrm{P}}^{\prime \mathrm{P}}$, should be zero in this range of phosphorus concentration. Assuming that only the first order term of carbon concentration affects on the activity coefficient of phosphorus in carbon-saturated iron, the logarithmic value of the coefficient is described by

$$
\log f_{\mathrm{P}}=e_{\mathrm{P}}^{\prime \mathrm{C}}[\% \mathrm{C}]
$$

where $[\% \mathrm{C}]$ is the carbon saturated concentration in mass $\%$. The $[\% \mathrm{C}]$ at each temperature is known to be described by Eq. (8). ${ }^{22)}$ The values of calculated by Eq. (8) were used in the calculation of $e_{\mathrm{P}}^{\prime \mathrm{C}}$. Although the carbon saturated concentration could be influenced by phosphorus content, this influence is insignificant compared with the scattering of the measured vapor pressures, and thus it was ignored in the calculation of the interaction parameter.

$$
[\% \mathrm{C}]=0.65+2.54 \times 10^{-3} \times T / \mathrm{K}(\operatorname{mass} \%)
$$

Figure 5 shows the logarithmic values $e_{\mathrm{P}}^{\prime \mathrm{C}}$ of as the function of temperature. An analytical equation is given as

$$
e_{\mathrm{P}}^{\prime \mathrm{C}}=\frac{120}{T}+0.061( \pm 0.010)
$$

As expected from the effect of phosphorus concentration on the saturated concentration of carbon, the value of $e_{\mathrm{P}}^{\prime \mathrm{C}}$ is positive. The $e_{\mathrm{P}}^{\prime \mathrm{C}}$ obtained in the present study is obviously in good agreement with that determined by Tsukihashi et al., ${ }^{12)}$ since their values were also determined from the $f_{\mathrm{P}}$ based on the same assumptions as used here. Although Eq. (9) was obtained by the measurement at 1473-1673 K, at $1873 \mathrm{~K}$ is calculated to be 0.125 by extrapolating Eq. (9). This extrapolated value agrees well with the data obtained by Hardry and Frohberg ${ }^{9)}$ at $1873 \mathrm{~K}, e_{\mathrm{P}}^{\prime \mathrm{C}}=0.128$, which is

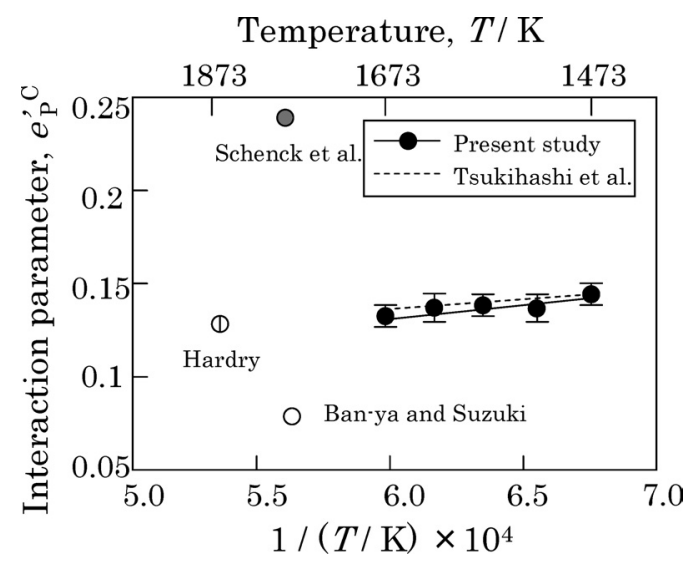

Fig. 5. Interaction parameter of carbon on phosphorus in iron as a function of temperature. the recommended value of equilibrium reaction in the steel making process. ${ }^{12)}$

\section{Conclusions}

(1) The pressures of $\mathrm{P}_{2}$ in equilibrium with $\mathrm{Fe}-\mathrm{P}-$ C(sat.) alloys at 1473-1673 K could be directly measured by double Knudsen cell mass spectrometry using $\mathrm{Cu}-\mathrm{P}$ alloy as a reference substance.

(2) The square root of the $\mathrm{P}_{2}$ pressure was proportional to the phosphorus concentration of the $\mathrm{Fe}-\mathrm{P}-\mathrm{C}$ (sat.) alloy, indicating that phosphorus in the $\mathrm{Fe}-\mathrm{P}-\mathrm{C}$ (sat.) alloy obeyed Henry's law below the concentration of 0.92 mass $\%$.

(3) The activity coefficient of phosphorus in molten carbon-saturated iron and interaction parameter of carbon on phosphorus in iron were obtained as follows:

$$
\begin{aligned}
& \log f_{\mathrm{P}}=\frac{300}{T}+0.82( \pm 0.05), \\
& e_{\mathrm{P}}^{\prime \mathrm{C}}=\frac{120}{T}+0.061( \pm 0.010)
\end{aligned}
$$

\section{Acknowledgement}

The authors thank Professor K. Morita of the Institute of Industrial Science of the University of Tokyo for helpful discussion.

\section{REFERENCES}

1) H. Schenck, E. Steinmetz and R. Gohlke: Arch. Eisenhüttenwes., 37 (1966), 775.

2) H. Schenck and H. Hinze: Arch. Eisenhüttenwes., 37 (1966), 545.

3) S. Ban-ya and Y. Matoba: Tetsu-to-Hagané, 49 (1963), 666.

4) F. Aratani, Y. Omori and K. Sanbongi: Tetsu-to-Hagané, 54 (1968), 143.

5) J. B. Booky, F. D. Richardson and A. J. E. Welch: J. Iron Steel. Inst., 174 (1952), 404.

6) G. Urbain: Mem. Sci. Rev. Metall., 56 (1959), 529.

7) S. Ban-ya, N. Maruyama and S. Fujino: Tetsu-to-Hagané, 68 (1982), 269.

8) S. Ban-ya and M. Suzuki: Tetsu-to-Hagané, 61 (1975), 2933.

9) H. G. Hardry and M. G. Frohberg: Metall. Trans., 1 (1970), 1867.

10) M. G. Frohberg, J. F. Elliott and H. G. Hardry: Arch. Eisenhüttenwes., 39 (1968) 587.

11) H. Schenck and H. Hinze: Arch. Eisenhüttenwes., 37 (1966), 919.

12) F. Tsukihashi, M. Nakamura, T. Orimoto and N. Sano: Tetsu-toHagané, 76 (1990), 1664.

13) M. Heyrman, C. Chatillon, H. Collas and J. Chemin: Rapid Commun. Mass Spectrom., 18 (2004), 163.

14) A. Büchler and J. L. Stauffer: Thermodynamics, Vol. 1, International Atomic Energy Agency, Vienna, (1966), 271.

15) W. H. Han, M. Miyake, Y. Mistuda and M. Maeda: High Temp. Mater. Process., 23 (2004), 399.

16) M. Iwase, E. Ichise and N. Yamada: Steel Res., 56 (1985), 319.

17) M. Knudsen: Ann. Phy., 28 (1909), 999.

18) K. Mita, S. Yamaguchi and M. Maeda: Metall. Mater. Trans. B, 35B (2004), 487.

19) W. Bleakney: Phys. Rev., 36 (1930), 1303

20) D. A. Skoog and J. L. Leary: Principles of Instrumental Analysis, 2nd ed., Saunders, New York, (1985), 305.

21) M. Yamamoto, K. Yamada, L. L. Meshkov and E. Kato: Tetsu-toHagané, 66 (1980), 2032.

22) J. F. Elliott, M. Gleiser and V. Ramakrishan: Thermochemistry for Steelmaking, Vol. 2, Addison-Wesley Publishing Company Inc., Reading, MA, (1963), 502. 